doi: $10.12957 /$ childphilo.2020.37827

\title{
philosophical dialogue with children about complex social issues: a debate about texts and practices
}

\author{
steve williams ${ }^{1}$ \\ p4c co-operative and sapere, united kingdom \\ orcid id: https:/ / orcid.org/0000-0002-1115-2988
}

\begin{abstract}
In this article, I report on my reading of a debate between two practitioners and scholars of philosophy with children - Karin Murris and Darren Chetty. The parts of their exchanges I have chosen to focus on relate to a children's book called Tusk Tusk by David McKee. Their respective arguments raise questions for me about the relationship between the starting text (or stimulus) and issues of importance in the wider world. Although Chetty sees benefits in using picture books, he appears to believe there is an over-reliance on fables and other magical tales and that alternative starting points could be more suitable for exploring complex social issues with historical dimensions. Murris, on the other hand, seems to appreciate the lack of historical perspective that is evident in many of her preferred picture books. She values their 'universal' and 'magical' aspects because they stimulate 'rhizomatic' dialogues that are spontaneous and non-hierarchical. In this commentary I trace what, to me, are the most significant lines of argument put forward by Chetty and Murris. In response, I suggest some practical ideas for choosing texts and 'reading against the text' - a term both writers use. I also ask and answer the question: 'In sessions of philosophical dialogue, should adults bring to children for consideration issues they regard as important or refrain from doing so?'
\end{abstract}

keywords: murris; chetty; race; history; dialogue.

\section{dialogo filosófico con niños sobre cuestiones sociales complexas: un debate sobre textos y practicas}

\section{resumen}

En este articulo describo mi perspectiva de un dialogo intelectual que tuvieron dos expertos de Filosofía Para Niños, Karin Murris y Darren Chetty. La parte del discurso de ellos en la cual me voy a concentrar en este artículo se basa en su discusión del libro Tusk Tusk, de David McKee. Las opiniones que expresan me hacen especular sobre la relación que existe entre el estímulo que uno elige para empezar los diálogos filosóficos y temas de importancia relacionados al mundo en que vivimos. Chetty aprecia que existe valor en usar libros de niños ilustrados para empezar el diálogo filosófico pero al mismo tiempo explica que los maestros usan fabulas y historias mágicas en forma excesiva y les recomienda que busquen otras alternativas cuando uno quiere explorar temas sociales e históricos. Murris, en contraste, es consciente que los libros que ella prefiere usar, aunque no den la oportunidad de considerar perspectivas basadas en la historia del mundo, sirven para promover al máximo los diálogos rizomáticos, espontáneos y sin jerarquía. En este artículo analizo lo que para mí son las opiniones principales de Murris y Chetty. Este análisis me deja ofrecer en este articulo varias ideas practicas que se pueden considerar al elegir un texto como estímulo del dialogo filosófico

\footnotetext{
${ }^{1}$ E-mail: steve@thinkingscripts.co.uk
} 
y también de cómo este texto se debe leer con los alumnos. También propongo y contesto la pregunta: ¿En sesiones de diálogos filosóficos es importante o no que los adultos pongan al frente de la discusión temas que ellos mismos consideran importantes para discutir?

palabras claves: murris; chetty; raza; historia; diálogo.

\section{diálogo filosófico com crianças sobre questões sociais complexas: um debate sobre textos e práticas}

\section{resumo}

Neste artigo, me refiro à leitura que faço de um debate entre dois estudiosos e praticantes de filosofia com crianças - Karin Murris e Darren Chetty. Os pontos da discussão entre eles que escolhi para focar remontam a um livro infantil chamado Tusk Tusk, de David McKee. Os argumentos dos dois, para mim, levantam questões sobre a relação entre o texto inicial (ou estímulo) e temas relevantes para pensar o mundo de forma ampla. Embora Chetty veja benefícios no uso de livros ilustrados, ele parece acreditar que há um uso excessivo de fábulas e contos mágicos e que outros pontos de partida possam fazer mais sentido para explorar questões sociais complexas com dimensões históricas. Murris, por outro lado, parece achar interessante a falta de perspectiva histórica evidentes naqueles livros de que mais gosta. Ela valoriza os aspectos 'universais' e 'mágicos' na medida em que estes estimulam diálogos 'rizomáticos', espontâneos e não-hierárquicos. Neste texto eu comento aquelas que, para mim, são as linhas argumentativas mais significativas nas perspectivas de Chetty e Murris. A partir dai, sugiro algumas ideias práticas para a escolha de textos e para 'ler contra o texto' - um termo que ambos autores usam. Ademais, pergunto e respondo a seguinte questão: 'Em sessões de diálogo filosófico, devem os adultos trazer para as crianças questões que eles consideram importantes ou é melhor evitar fazê-lo?'

palavras-chave: murris; chetty; corrida; história; diálogo. 
philosophical dialogue with children about complex social issues: a debate about texts and practices

part 1: the debate between chetty and murris

\section{philosophising with picture books}

In the UK, many of those who practice philosophising with children have followed Karin Murris and Joanna Haynes down the road of using picture-books as their preferred starting points for enquiry ${ }^{2}$. The first decision to be made en-route is: 'Which ones should be chosen?'

Haynes and Murris (2012) provide a list of things they 'look out for' (p. 119) when selecting picture books.

They value, among other things, 'high quality artwork (written and visual)' (p. 120) in stories 'engaging emotions and imagination' (p. 120), ambiguity and complexity' and in which there is 'playful opposition to authority, seriousness and conformity' (p. 120). They tend to favour stories that are complex and feature 'abstract concepts and topics' (p. 120). In a chapter arguing for the value of using picture books as starting points for philosophical dialogue with children they write: 'We see it as our challenge to use educational resources that generate philosophical questions and topics worth exploring' (p. 68). They distance themselves from stories with overt moralising messages and from adults who use stories to promote their own moral agendas. They argue against the censorship of books by teachers who disapprove (or feel other adults would disapprove) of the content.

Like many other practitioners and advocates of P4C, Murris and Haynes have high expectations for philosophical enquiry, including dialogue about complex social issues: 'All the evidence is that situated dialogue that includes communication about class, cultural, racial and gendered positions is at the heart of education and social transformation (p. 58).'

\footnotetext{
2 Tim Sprod (1993) was also an early advocate for using children picture books but only as one approach amongst others.
} 
I think it unlikely they would identify a sharp binary divide between messagebearing or closed texts and ambiguous open ones. All texts are organised to emphasise some aspects of experience and understate others. They write: 'Often stories will tempt the reader to draw certain morals ... In philosophy the facilitator can encourage children to think for themselves and to critique the implicit and explicit assumptions of a story (p. 46)'

\section{'tusk tusk': a contested picture book}

Darren Chetty (2014) addresses a similar point with reference to a story recommended by Haynes and Murris. Tusk Tusk is a picture book written and illustrated by David McKee (1978). The gist of the story is that in an imaginary world where elephants are either black or white, the two types hate each other and keep to their own side of the jungle. Then one day they decide to kill each other and they do, but not before some peace-loving elephants are able to sneak off into the deepest jungle. Eventually, their grandchildren come out of the jungle and they are all grey. The story ends with these words: 'Since then, the elephants have lived in peace. But recently the little ears and the big ears have been giving each other strange looks.' So hatred leads to violence. But where does the hatred come from?

Chetty (2014) argues that the story is not ambiguous and complex enough; rather there is a strong steer towards 'irrational hatred of difference' as a default explanation for the carnage. He suggests a possible implication that humans in the real world as well as animals in this imaginary one naturally grow to hate those who are different. While this might not be a moral in the sense of a clear maxim for conduct, it nevertheless conveys a message or lesson to be learned about the way things are in the world. There are no clues in the story pointing to other possible reasons why the perception of difference should turn to antipathy and then violence. Chetty suggests McKee's work can be seen as a fable. He writes:

The conflict appears to have its origins in murderous, irrational hatred of difference, rather than any desire for land, resources and power. The hatred precedes the violence and does not grow out if it. It appears to 
be caused by the difference rather than the difference being constructed as significant due to the situation. If we read the story as an allegory of race, its ahistoricism is potentially mis-educative; there is little to help children make sense of current racial tensions, save the possible implication that we naturally hate those who are different from us ( $\mathrm{p}$. 21).

In other words, the message of the fable would be: prejudice turning to antipathy is natural. Chetty expands on his theme:

[...] the absence of culture, geography, power imbalances, indigenous and non-indigenous, religion, language diversity, history and racism leads to allegories of racism that have simplified to the point of falsifying. Indeed we could argue that the two books constitute a form of ideology, in the sense of being fables that conceal reality (p. 24)

Murris and Haynes (2012, p. 46) have argued that: 'In philosophy the facilitator can encourage children to think for themselves and to critique the implicit and explicit assumptions of a story.' They add: 'Implicit and explicit value positions can and should be questioned through educational activities that require readers to make a conscious effort to "read against texts" and to "deconstruct them"”.

Chetty (2014, p. 23) considers the idea of 'reading against the text' but suggests this needs to be developed more than is currently the case in the literature of philosophising with children including the mention it gets by Haynes and Murris, (2012, p. 46). However, he does see some potential benefits in this strategy and asks: 'Should we be signalling more clearly that reading against the text is a useful, perhaps essential, skill to develop? The practice of philosophical enquiry would seem the very place where those skills could and should be learnt'. He offers no suggestions himself but rather he challenges others to put forward ideas. Later in this article I take up that challenge.

Chetty suggests there may be a limit to what popular picture books alone can achieve in supporting dialogue about complex social issues with historical dimensions. I agree. Murris refers to Chetty's article in one of her own. She writes:

Adults often prefer to use picture books didactically and tend to listen to children's comments literally (see, e.g., Chetty). Further, humanist approaches to literacy that are theoretically positioned in poststructuralism regard education as a formation of the child into an adult 
- assuming and emphasizing binary opposites (e.g., child/adult) instead of playing with and blurring them. For example, Critical Race theory assumes the ontological distinction between nature and culture as fixed in its theorizing of race as a social construct (Chetty, 2014). Chetty argues that certain picture books should be avoided because their 'temporal and spatial realities' have been removed, and thereby, such books 'reaffirm the discourse of [in this case] Whiteness' in that 'The story appears to exist independently of history' (2015a, p. 60).

I see no evidence in Chetty's article to support Murris's assertion that he wants teachers to avoid using Tusk Tusk per se, or that he wants teachers to use picture books didactically, or that he regards the distinction between nature and culture as fixed, or that he presents a conception of the relationship between childhood and adulthood. He does claim that the use of Tusk Tusk in P4C is 'potentially mis-educative' (p. 21). However, I don't think this implies he demands materials be educative in a didactic sense - only that he objects to the 'stimulus' for enquiry being limited to what he judges as a false presentation of the roots of racial conflict (in the sense of hatred targeted to those with different bodily appearances).

One presentation of the roots of racial discrimination that could support Chetty's critique of Tusk Tusk as being 'potentially mis-educative' is put forward by Ibram X. Kendi, the author of Stamped from the beginning: The definitive history of racist ideas in America:

I was taught the popular folktale of racism: that ignorant and hateful people had produced racist ideas, and that these racist people had instituted racist policies. But when I learned the motives behind the production of many of America's most influentially racist ideas it became quite obvious that this folktale, though sensible, was not based on a firm footing of historical evidence. Ignorance/hate $->$ racist ideas $\rightarrow$ discrimination: This causal relationship is largely ahistorical. It has actually been the reverse relationship - racial discrimination led to racist ideas which led to ignorance and hate. Racial discrimination >racist ideas-> ignorance/hate: This is the causal relationship driving America's history of race relations (2016, p. 9).

Murris (2015a, p. 60) criticises Chetty for 'theorising race as a social construct' in contrast to her own preferred practice of 'blurring of binary opposites' such as nature and culture. What might such a blurring look like and where could it lead? Murris provides little guidance apart from pointing out that 'picture books feature creatures 
that mediate between binary opposites' - an example in Tusk Tusk being: 'elephants that use their trunks as guns' $(2016$, p. 208).

Psychologist Lawrence Hirschfield (1997) explores the relationship between nature, culture and politics after a combination of empirical research and speculation. In his view, racial thinking emerges out of the operation of a more general humankind mode of reasoning about difference. He argues from empirical studies that it is 'natural' for humans to notice differences and essentialise those differences - in other words to make assumptions about many qualities of people based on knowledge of only one. Markers of racial difference, among others, tend to get noticed. He then claims that systems of power and domination (developed historically) continue to make contact with and recruit race because it is 'easy to think'. In doing so our 'cognitive architecture makes political architecture possible' (p. 87). Whatever one thinks of Hirschfield's conclusions, his is a serious attempt to gain better understanding of racial thinking and racial domination. His work adds weight to the conclusions of Ibram X. Kendi quoted earlier about the history of racist ideas in America.

I think Chetty is simply saying he doesn't think Tusk Tusk is a good starting point for one sort of dialogue Haynes and Murris claim they want to see: '... situated dialogue that includes communication about class, cultural, racial and gendered positions' (2012, p. 46). One of his reasons is that the implied message of Tusk Tusk - that irrational hatred of difference arises naturally, and perhaps unavoidably - is all too clear. In this story there is a lack of the sort of conceptual blending of opposites in the area of nature/culture that Murris favours. Nor is there any blending with related concepts that, though not opposite, combine together to offer a complex web of meaning - domination, exploitation, history and so on.

Chetty's argument seems to be that it is not likely that children's picture books alone, particularly in the form of fables, can present this level of complexity and 'blending'. I take him to imply that other kinds of picture books and alternative materials - or combinations of materials - might be more suitable for exploring complex social issues with historical dimensions. 


\section{rhizomatic dialogue and adult agendas}

In a recent book Murris (2016) refers to Chetty's article. She advocates the idea that philosophising with children should be a 'rhizomatic' activity'. She explains 'rhizome' - a term she adopts from philosophers Deleuze and Guattari - as 'knowledge that is constructed as non-hierarchical, without root trunk and branches, but is something that shoots in all directions' (p. 12)

In this book Murris seems to have moved away from the position she took with Haynes in 2012 in accepting the '... challenge to use educational resources that generate philosophical questions and topics worth exploring' (p. 68)

One aspect of educational hierarchy she is now more wary of is the practice whereby adults choose issues and perspectives to overtly bring to the attention of children. She implies that Chetty has a set of preferred answers about the issue of race that he wants children to consider and possibly accept. Murris claims to be against practices of adult moralising through the choice of text, the setting of the agenda for discussion or the manipulation of dialogue.

At times, Murris's writing seems inconsistent on the matter of moralising. For example, she writes approvingly of one of her favourite children's authors, Anthony Browne:

The political message is obvious; the real monsters Brown insists are the human animals who keep nonhuman animals in captivity. The dialogues with children show a clear emotional cognitive engagement with Brown's political message, and their concern about the plight of the two gorillas is evident (2016, p. 214).

Surprisingly, given her own preference for the blending of opposites, she makes a distinction between the acts of emptying people of 'unexamined ideas' and filling them with ideas (2016, p. 228). She seems to approve of the former and disapproves of the latter. Writing about her work with her university students, she is clear about the sorts of ideas she wants to empty them of: 'The year's course should have left marks on their bodyminds and "erased" modernist assumptions about child as subject.' (2016, p. 30). She does not seem to allow for people wanting to retain some of their (relatively) unexamined ideas once they have examined them further or of adopting, after 
examination, new ideas offered by others. When people choose to discard some of their notions, the reason is often that they have been offered or discovered alternatives and judged them to be better. Some of Murris's students may have 'erased' their modernist assumptions not least because she has offered them alternative 'post-humanist' ideas they found convincing - though I doubt she would accept that she was 'filling them up' with her own ideas.

So far as Chetty is concerned, I think a distinction should be made between wishing to bring certain matters to the attention of children and trying to control the agenda and the outcome. I think he wants to do the former. I see no evidence that he advocates the latter, though Murris presents him as wanting to do both. Also, Chetty does not suggest that only adults should choose materials and topics, only that some important topics and perspectives should not be overlooked.

So, for example, a teacher may offer a book to children because it depicts 'playful opposition to authority, seriousness, and conformity (with stretched, broken or abandoned rules)' (Haynes and Murris, 2012, p120.). Another may offer a book that offers an historical depiction of racial conflict. The second teacher might say 'I' $m$ inviting you to read this book because I think racial conflict and the concept of race are important. What do you think?' The first teacher may also give a reason for her choice. She might say ' $I$ ' $m$ inviting you to read this book because it depicts playful opposition to authority, seriousness and conformity,' but she would probably say 'I think you'll enjoy it'. I do think it's good practice on the ground of openness, to share one's criteria for choosing materials with children. Both these teachers are bringing something to the attention of children. However, if a teacher said something like: 'Let's think of questions about why we should respect others' or showed approval or disapproval depending on whether or not children said things she wanted to hear, then that would count as trying to control the agenda and the outcome. 


\section{picture books, race, universals and history}

Throughout her new book, Murris gives the impression that carefully selected picture books are not just one possible starting point for philosophising with children but the ideal starting point for all philosophising with all ages, not least because she claims they 'destabilise binaries' and combat 'ontoepistemic injustice' (2016, p. 204)32. One such 'binary' she seems to have in mind with regard to her debate with Chetty about Tusk Tusk concerns the qualities historical and universal.

Murris uses folk-tale expert Jack Zipes as an authority to support her conviction that lack of historical context in stories is an advantage in that it supports her preferred 'rhizomatic approach' to philosophising with children.

She uses his words as follows: "If we "dissect or study" such tales "in a sociopolitical context ... that might ruin their magic power" (2016, p. 245) Unfortunately, I think this is a misinterpretation of Zipes's views. Zipes is in fact arguing the opposite - that the historical and socio-political context of fairy tales should be considered. The words Murris chooses to quote are part of a passage where he is setting up a position commonly held by others he intends to oppose. The passage, without Murris's deletions, reads as follows (with my italics):

The best fairy tales are supposedly universal. It does not matter when or why they were written. What matters is their enchantment as though their bedtime manner can always be put to soothe the anxieties of children or help them therapeutically to realize who they are. One should not dissect or study fairy tales in a socio-political context, for that might ruin their magic power. (Zipes, 2012, pp. 1-2)

That Zipes believes the socio-political context of fairy tales should be studied is exemplified throughout the rest of the chapter. He sums up his own position as follows:

The fairy tales we come to revere as classical are not ageless, universal and beautiful in and of themselves, and they are not the best therapy in the world for children. They are historical prescriptions, internalised, potent, explosive, and we acknowledge the power they hold over our

\footnotetext{
${ }^{3}$ Ontoepistemic injustice is a complex notion that Murris creates out of her readings of Karen Barad and Miranda Fricker (MURRIS, 2016, 247 n1). Aspects of such injustice include adults determining what is worthwhile learning (p.131) and what counts as true knowledge (p.130).
} 
lives by mystifying them (p. 11).

Zipes's intentions and the direction of his life's work are even clearer in the title of another of his books: Breaking the Magic Spell (1979)

If, as Murris suggests, the universal is a more engaging and rhizomatically fruitful presence than the historical and contextual, the question still arises: What universals are being advanced in the Tusk Tusk story and to what end? Zipes (2012, xii) writes that the 'art of the fairy tale provides a means of understanding the real world through standard metaphorical clichés as well as through highly innovative articulations and inferences.' For Chetty, it seems, the cliché that is central to this story is something like this: beings are naturally inclined to be antipathetic towards difference even to the point of violence (p. 21). Even if children's 'rhizomatic' questions about the story do not refer to this cliché, the children might still be influenced by it. If Murris is worried about adult perceptions being passed along, then would this not also apply to perceptions embedded in stories that do not happen to be questioned by children for reasons unknown? Children may accept an underlying story cliché without question and, through it, a potent - though dubious - adult perception.

A reference to framing theory may be helpful. Frames are representations and simplifications of reality. They are schema that individuals use as tools for interpreting and filtering their experience. A schema that suggests it's natural to hate beings that are different may encourage readers to filter their experience accordingly, to find examples of that phenomenon and to re-frame their own perceptions to some degree.

Murris relies on the relational triangle of text, educator and learners to provide all the necessary resources for 'critical enquiry-based learning' (2016, p. 243). In such a triadic relationship, she expects 'the world' to 'leak into our classrooms' (2016, p. 230). That may be the case, but it may also be the case there are not enough worlds leaking in; there are no alternative texts or schema, no other frames of interpretation that would either enlighten teachers and children or encourage them to express an alternative point of view. Murris is rightly critical of the tendency to see children as being 'not only innocent but ignorant' (2016, p. 230). But, surely no one is free of ignorance. A little 
history should be welcomed when people fall upon concepts and presuppositions that have complex historical roots.

Murris seems to be wedded to picture books with little cultural and historical specificity. For example, Haynes and Murris write:

In a sense it is ironic that the more ambiguous and the less culturally, historically, politically and morally specific a starting point for enquiry is, the more likely it is that members of a community will experience a sense of freedom to connect with the picture book narrative on the basis of their own cultural and personal identities. (2012, p. 68)

They provide no evidence to support their claim, nor do they qualify it with a phrase like: 'In our work we have observed that ...' But their claim seems to close down the space for experimenting with materials of greater verisimilitude or with more overt historical and social context. That would be a shame, since I believe that such experimentation is desirable. I will suggest some alternative ways to use texts and activities in the remainder of this article. Also, it could be argued, as Zipes does, that fantastical stories are indeed culturally, historically, politically and morally specific in their own ways and should be recognised as such rather.

part 2: more ideas about texts and activities for 'reading against the text'

\section{some additional and alternative texts}

I don't have the space in this article for an account of non-fiction texts and their potential or otherwise in philosophical enquiry. However, it is worth saying that there is a wide range of types of non-fiction texts available for different age groups. For example:

- Testimonies often presented as 'voices' situated historically and socially.

- Arguments (for example Let's Talk about Race by Julius Lester).

- Issue-based books providing more or less historical context (for example Africa and the Slave Trade by Dan Lyndon) 
- News articles about current events ${ }^{4}$

- Biographies of historical figures who displayed virtues in the face of testing times (for example Who Was Rosa Parks by Yona McDonough Zeldis)

Using non-fiction texts can be problematic. There are distinctive challenges. However, they can, at the very least, be good additional resources for the p4c classroom. In my own experience, I find that when children have argued about a question, they often want to find out more about what is the case in the world. They want to think about what has happened, what is happening and what might happen in the future. As Margaret Meek (1996) writes: 'Before long, a growing interest in particular topics encourages them to remember which books tell them what they want to know or remember.'

What then of picture books and other stories with greater social and historical context? One picture book with some themes that are similar to Tusk Tusk is The Other Side by Jacqueline Woodson, with illustrations by E. B. Lewis (2001). The story is set in a small rural town in America during the years of segregation. The beautiful illustrations give a feel of the late fifties or early sixties.

The narrator and protagonist of the story is Clover, a young African-American girl. She lives beside a fence that segregates her town. Her mother instructs her never to climb over to the other side because it isn't safe and 'that's the way it's always been'. Then one summer, she notices a white girl on the other side of the fence. The two girls are drawn towards each other.

With neither girl being allowed to cross the fence, they simply decide to sit on it together and talk. Although Clover's friends have previously rejected Annie, they eventually relent and a new, inclusive group is formed. The fence is finally breached as the children play together. Clover's mother seems pleased with the outcome.

\footnotetext{
${ }^{4}$ Roger Sutcliffe and I produced a series of articles with suggestions for enquiry over a period of several years as part of project called Newswise. One of those was about the racist murder of Stephen Lawrence on the streets of London in 1993. It is currently available at the website p4c.com.
} 
Jacqueline Woodson, the author, comments: 'I wanted to write about how powerful kids can be. Clover and Annie fight against segregation by becoming friends. They don't believe in the ideas adults have about things so they do what they can to change the world. We all have this power (2018).'

Like Tusk Tusk, Woodson's book deals with separation based on body markers. However, there are significant differences:

- The central characters are humans, not elephants.

- The story is historically and culturally situated rather than being placed in a magical non-historical setting.

- An individual is seen influencing group-think and so changing a situation. The elephants act in groups based on characteristics such as being hate-inclined or peace-loving. Suspicion of others seems to be a persistent group tendency.

- The illustrations that complement the story are more realistic than in Tusk Tusk.

- The suspicion between racialised groups is placed in the historical context of segregation in America. The suspicion between the elephants arises from arbitrary responses to body markers such as skin colour and ear size.

- The ending is more hopeful in Woodson's story. In the enjoyment of each other's company, children disregard historical pressures pushing them towards segregation, suspicion and possible future antipathy.

Although The Other Side presents children going against the advice of adults, one could argue that the outcome of the story would gain approval from many teachers. They could wholeheartedly recommend it because it presents characters that eschew prejudice in favour of friendship and acceptance. Would that be a reason enough for not using the book as a starting point for philosophising? I don't think so. It would be a strange sort of educational philosophy that ruled out books with characters who prefer openness and friendship to suspicion and hostility simply 
because those qualities are likely to be endorsed by their teachers. The important point is how this book might be used to support enquiry.

In fact, there is scope for a wide range of questions around The Other Side concerning, for example, the authority of adults, the agency and judgement of children, the nature and consequences of boundaries, the exercise of choice in light of the possible consequences and the roots of racial categorisation. I'm sure children themselves would find much to question and reflect upon.

However, I do not intend to argue that either Tusk Tusk or The Other Side should be rejected in favour of the other. I would rather say they could both be used - along with non-fiction materials (including films) to provide children with the opportunity to talk about issues of racial domination, conflict and resistance. I readily concede that by choosing books with similar themes I would be preparing in advance for those to be significant foci of attention. However, I think that by bringing these resources together, children will have greater opportunities to develop their own interests, perspectives and judgements.

Mikhail Bakhtin, the Russian philosopher of dialogue and language, referred to processes like these as creating 'dialogic relations' between texts. He writes:

Dialogic relations are relations (semantic) among any utterances in speech communication. Any two utterances on a semantic plane (not as things and not as linguistic examples) end up in a dialogic relationship ... (for example, the selection of various utterances of various scholars or sages of various eras on a single question) (1986, p. 117).

This passage suggests to me that when texts on similar themes but with different styles and perspectives are brought together, there is potential for a new synergy of questioning and reflection to come about. I think this is particularly true when there is an intention to engage children in, to quote Haynes and Murris, 'communication about class, cultural, racial and gendered positions' (p. 58).' I agree with Chetty that using Tusk Tusk alone would be limiting - notwithstanding Murris's useful emphasis on the importance of 'the relational triangle between text, educator and learners within an environment that supports and encourages enquiry-based learning' (2016, p. 243). 
Murris is right to say that choice of text is not the only determinant of enquiry but it makes a significant contribution nevertheless. If a range of texts (e.g., fiction and nonfiction, realistic and fantastic, narratives and lists) can be brought into dialogical relations then even the sort of 'rhizomatic' dialogue that Murris favours is more likely because, not only are there more opportunities for enquiries to 'shoot out in all directions', but also the influence of the single author is curtailed. The authority of the author's voice is reduced when it becomes one among others. There will also be less scope for the mis-education about racism that Chetty wants to avoid - depending, of course, on which other texts are chosen.

\section{how to 'read against the text'}

Murris writes that: 'Training in philosophy with children should explicitly include the role of the teacher in 'reading against the text.' (2016, p. 232). Chetty sees positive possibilities in this and asks what it might mean in practice (2014). Neither Murris nor Chetty explain what they mean by 'reading against the text nor to they give examples. In her book of 2016, The Posthuman Child, Murris reports on an activity with children around Tusk Tusk that could be taken as an example of 'reading against the text' although she doesn't label it as such.

I will explain what I take from the phrase, describe Murris's activity and go on to make some further suggestions.

'Reading against the text' is associated with the 'critical literacy' movement. When the phrase 'reading against' a text is used, there is usually an assumption of a plurality of potential meanings available to the reader. There is also a focus of attention on the ways the text shapes and limits the construction of meanings. Contradictions, gaps, inclusions, exclusions, alternative possibilities for plot, language and images are

considered and assessed. Readers are encouraged to consider the consequences of the authors' choices and also of their own. Murris writes that the power of Tusk Tusk is '...what it leaves out. It has not been written for educational purposes', though the story contains abstract concepts with which readers can engage if they wish (2016, p. 
243). I assume an important purpose of the book is to give pleasure to readers. One response to this from a critical-literacy perspective would be (in the words of Alastair West): 'What is the price that the reader has to pay for being worked on by the text, for getting whatever pleasure is on offer?' (1994, p. 87). This is a question for the teacher to consider when planning a sequence of activities using the book.

Murris makes two reasonable points about philosophising with children that would allow scope not only for thorough philosophical reflection but also reading against the text.

- '... sessions should be part of larger projects rather than being contained to one hour isolated lessons' (2016, p. 232).

- 'Philosophy for Children relies on the relational triangle: text, educator, learners "within" an environment that supports critical enquiry-based learning' (2016, p. 243).

She then describes an activity with children as follows:

My use of a well-known storytelling device of interrupting a story read out loud and by letting them speculate about various story endings supported the philosophical work. Without knowing what was going to happen, and by looking at the double page spread of the maze only, the children suggested some of the following rich narrative scenarios: 'The black and white elephants are 'fighting' 'making friends', 'mating', 'sleeping in the middle', 'having wars over the golden treasure' and 'they are jealous' ... Their maze drawings had agency: they offered opportunities to the children to construct their own meanings and to link the story with their own prior knowledge and experiences (2016, pp. 239-240).

To my mind, this is an example of critical literacy in the (albeit limited) sense that it fosters awareness that stories are constructed, from a number of possible alternatives, by an author. Murris describes a process of encouraging the children to express their ideas which, she writes, were: 'sometimes in tension with the main idea of the story that the elephants were fighting because one group was white and the other was black'. Murris appreciates the children's ideas and it seems she helped them to see connections using what she calls a 'text-ile of connectedness'. Although I found no explanation from Murris of the term 'text-ile', I imagined it as something like a piece 
of cloth laid out on the floor with children's ideas (writings and drawings) arranged on it. Children might be gathered around noticing connections and talking about them. Murris writes: 'the maze activity turned out to trigger very diverse and imaginative ideas' and the children '... felt at ease in the playful and intellectual juggling of ideas' (2016, p. 241). In the next three sections I offer some ideas for 'reading against the text' of Tusk Tusk building on what Murris has described.

\section{reading against the text using evaluative judgement}

When children create alternative plots, images and words, one possible activity is for them to evaluate their creations. Which are the best and why? Invention is combined with judgement and judgement prompts children to articulate criteria (standards used for judging). Some possible criteria for justifying preferences for certain stories are:

- It's pleasurable (for example: funny surprising, imaginative, silly).

- It's more true to life (for example: 'People don't start fighting over nothing!').

- It fits better with other parts of the story.

- It's similar to other stories.

- It's admirable (for example: the fairest/least cruel/admirable outcome would be such and such).

Through the experience of judging, children become not only aware that stories are constructed and that various alternatives are possible, they are also invited to share their preferences and criteria. Their choices may be different from those of the author and they will be able to explain why. They might consider criteria that conflict or harmonise. So, for example, a child may judge that the most pleasurable story idea is not the most admirable or true to life. Other children might think otherwise - that it is 
possible for a story to be both pleasurable and true to life ${ }^{5}$. This kind of discussion relates to Alastair West's question: 'What is the price that the reader has to pay for being worked on by the text, for getting whatever pleasure is on offer?' (1994, p. 94). Children could take away ideas from an evaluative dialogue that would inform future aesthetic and ethical judgements. The dialogue itself would also provide opportunities for open questions such as 'In what sense, if any, can fictional stories be true to life and in what sense true?'

I've used the same strategy as Murris (of interrupting the story and asking children to make suggestions) many times. For me, it is a good choice for a story that I feel manipulates the reader a little too much or provides too powerful a sense of closure with a 'punch-line' style of ending. I often put the children into the position of characters in the story or advisers to characters. Then I ask: 'What should happen next?' I've found that they enjoy arguing about which are the best (and even the worst) suggestions.

One useful tool for engaging children's attention is a 'consultation board' (Warden, 1995, p. 63). Children's suggestions are added to a large whiteboard or flip chart divided into six or eight sections. Each suggestion is illustrated with an image and a label. When sufficient sections are completed, children are asked which they prefer and why. I've found this to be very satisfying for children, even when their own ideas are being criticised. I believe that judging is compatible with playfulness. For example, on one occasion I was discussing a story with some $6 / 7$ year-olds about a Frog called Tiddalick ${ }^{6}$ who had drunk all the water in the land. The other animals (children in role) had a meeting to decide what should be done. They made all kinds of suggestions for the consultation board: 'prick him'. 'make him laugh', 'jump on him,' 'squeeze him', 'trick him'. When we discussed their criteria, the two most popular

\footnotetext{
5 The previous strategy I mentioned of using multiple texts to illuminate a theme should help children to decide which story possibilities are truest to life by providing some alternative perspectives or 'frames'.

${ }^{6}$ I adapted the story I used after reading other versions of this Aboriginal folk-tale that I found on the Internet and had an illustrator make original images that I transferred to PowerPoint slides. These, along with teacher's notes are available on the website, p4c.com.
} 
were: effectiveness and absence of harm. One boy had suggested the following idea: 'make a rocket, put Tiddalick in the rocket, fly it into the sky, throw Tiddalick out of the rocket and then jump out of the rocket onto Tiddalick'. When it came to decision time, one girl said she thought that was the worst idea. I asked 'why?'

Girl: There's a lot that could go wrong.

Me: (to the boy): What do you think about that? Do you agree with her?

Boy: Yes.

Me: So, do you still think your idea is best?

Boy: Yes

Me: I'd like to hear your reason.

Boy: I just like rockets.

He was making the understandable judgement that the pleasure he got from his idea was worth more to him than its practicality. It was the sort of thing he would like to read about in a storybook. Most other children, however, thought that the situation was so serious that the criterion of effectiveness was most important.

If I asked children to evaluate their invented alternatives to parts of Tusk Tusk, I would listen to their evaluations but also be prepared to offer them general organising categories and concepts such as pleasure and truthfulness. Some educators might label that as having a 'deficit theory of childhood' because I regard my own conceptual awareness and linguistic repertoire as being greater than those of the children. I see it differently. In my view, I am enabling them to appropriate part of the cultural heritage of the past and use it for their own purposes. At the same time I am listening to and respecting what they say.

There are some significant advantages to the practice of developing criteria through evaluative judgement, such as:

- Other texts and artefacts can be evaluated using the same criteria. For example, a picture book like The Rabbits (Tan, 2010), with its greater implication of conquest, domination and exploitation, could be compared with Tusk Tusk, as could The Other Side (discussed at length 
above). Which stories do children find most pleasurable, truthful, affecting or ethically satisfying?

- Criteria can form the basis of research and the blending of fact and fiction within a sequence of sessions. For example, if someone makes a claim about how conflicts are most likely to begin, one could ask them if they would like to find out about any particular conflicts to see if their claim was a fair generalisation.

Research into conflicts could include those with racial inferiorization or racial antipathy as factors. Lawrence Blum $(2002$, p. 8$)$ suggests that all forms of racism can be related to one or both of these two general themes. Research could be undertaken at any stage during a child's education and not necessarily straight after reading a book such as Tusk Tusk. I am often surprised how much certain ideas can stick with individuals through time and facilitate future connection-making.

If children do not wish to exercise their judgement on ideas they have created themselves, some teacher-produced alternatives could be offered. Here, for example, are three alternative story beginnings:

1. Black and white elephants lived in different parts of the jungle. Between them, they ate most of the food until there was not enough to go around. That was when the fighting started. The white elephants said the black ones were no good and didn't deserve any food. The black ones said the same about the white ones.

2. Black and white elephants lived in different parts of the jungle. There was plenty of food for everyone but they just started to hate each other. None of them knew why. Then the fighting began.

3. Black and white elephants lived in different parts of the jungle. One day, an evil wizard put a magic spell on them. From then on the elephants hated each other. Then the fighting began.

4. Black and white elephants lived in different parts of the jungle. The white elephants ate most of the food in their part of the jungle and it made them 
big and powerful. They needed more food so they decided to raid the territory of the black elephants. They started to say that the black elephants were inferior and didn't deserve their food. That was when the fighting began.

Prior to sharing which beginnings they liked best and developing criteria, the children could identify similarities and differences between the options. They could also rank them according to criteria they had created:

5. Which beginnings are most interesting?

6. Which are most likely?

7. Which are most real?

8. Which are most fantastic?

It could be argued that in dialogue around the second and third criteria, children would benefit from some historical background knowledge in addition to their own accumulated experiences; without it they would be unable to question the potent story clichés on offer. My own view - as I mentioned in the earlier section on non-fiction resources - is that as soon as people engage with a question such as: 'Which story is most real?' there is a strong motivation to find out more to better inform judgements. This is an ideal time to make historical background materials available. Furthermore, if people find information that is illuminating, they will recognise the value of considering a criteria such as 'reality' or 'truthfulness'. It would become a critical tool they could appropriate for future encounters with texts. The teacher could encourage the children to be discriminating in their contributions to dialogue with questions like: 'In what way is this more real?' or 'In what sense is this more truthful'?

\section{reading against the text by questioning the concept of hatred}

If Chetty is right that the Tusk Tusk text presents hatred as 'natural' in humans, then a strategy for reading against the text could be to problematise the concept.

A short activity that focuses attention on a significant concept or process of reasoning is often a useful tool for enquiry and one that has been used extensively by 
Matthew Lipman and others around the world. Murris (2016, p. 232) recommends that '... sessions should be part of larger projects rather than being contained to one hour isolated lessons'. I agree. Concept and reasoning activities can be used productively in additional, linked sessions. I suggest that a concept activity focusing on 'hatred' could be useful as a strategy for 'reading against' Tusk Tusk' and stimulating further philosophical dialogue. One format for the activity is to create a dividing line in the classroom. You present children with a number of propositions (see below for examples) and ask them to stand on one side to agree and on the other to disagree. They share their reasons and then have the option to change their choices or their justifications. As an addition to this format I suggest to children that they can 'use an if or a when'. This allows them to qualify their choices: 'I agree with $\mathrm{X}$ if (or when) $\mathrm{Y}$ '.

The following activity is influenced by an article by the Polish philosopher Leszeck Kolakowski. In Education to Hatred, Education to Dignity (1990), he mentions three common 'leading ideas', which he says 'demand a response' (p. 256):

1. Hatred is natural and thus unavoidable.

2. Hatred is effective in any struggle, thus also in the struggle for justice.

3. Hatred may be justified morally since there are hateful people and things. In his response he argues in favour of the following alternatives (p. 256):

1. There is no right to hatred regardless of the circumstances.

2. It is absurd to say that somebody deserves hatred.

3. We are capable of living without hatred.

4. To renounce hatred in no way means to renounce struggle.

5. Right turns into wrong if it asserts itself by hatred; or - which amounts to the same - it is self destructive to employ hatred in the name of justice.

Kolakowski's article gave me food for thought. However, if I am planning an activity for philosophical enquiry then, like Murris and Chetty, I want to leave questions open for children to consider for themselves. In the light of this, I use some thoughts I had after reading the article for an activity in which children agree or 
disagree with some propositions. I wouldn't use all the statements below. Three or four is probably enough.

1. Hatred is sometimes unavoidable.

2. Some people deserve to be hated.

3. People can live without hating.

4. People can choose not to hate.

5. If a person gets angry with someone else, then they are likely to hate them.

6. A person can be angry without hating.

7. Animals can hate other animals.

8. Only humans hate.

I would describe activities like this as examples of 'reading against the text' and bringing something important to the attention of children without trying to control the outcome.

\section{reading against the text using reflective dialogues}

The dialogue form has some benefits and it could be used alongside picture books and factual material (see, for example: Williams, 2002). Considering and creating dialogues can assist the process of reflection. It is certainly possible to create a dialogue in response to the experience of reading another text such as Tusk Tusk. It isn't always necessary to provide a dialogue written by an adult. Here are some other ideas:

- Take advantage of a question that arises from conversations with children during any of the activities you have undertaken together. Ask them to take a notebook home with the question and for family or community members to write responses. Let them bring the responses back, compare them and work with the children to create a dialogue articulating different points of view. The dialogue itself could become a further focus for reflection. Individual children could create their own endings to the dialogue. 
- Spread a cloth on the floor and gather writing and drawings from children on a question. Again, work with them to create a dialogue.

- Write a dialogue yourself as a way of recording some of the things children said in your conversations with them. Read the dialogue together and add new thoughts or refinements so that it grows and develops. This is a task that can extend over days, weeks and even years. It would be interesting to have a group of children return each year to a dialogue they had previously created and re-create it. In this way, new factual and philosophical material could be considered at later stages.

Using written dialogues in these and other ways could also contribute to 'reading against the text' to the extent that resources for dialogue would include all the conversations around additional activities such as those described above. The creation of the dialogue would stimulate further reflection.

\section{conclusion}

I have commented on the debate between Chetty and Murris about the picture book Tusk Tusk. I have also suggested ways, in practice, of widening the scope of enquiry into concepts and situations of antipathy, inferiorisation, hatred, race and racism. I agree with Chetty that black perspectives and historical context should be included in the menu of texts available to children and young people (with the proviso that what counts as 'historical context' is contestable).

I have argued that a promising strategy for achieving this inclusion is to bring a range of texts into 'dialogical relations' so as to stimulate comparison, enquiry and evaluation. This also facilitates 'reading against' texts in the sense that the practice of comparing them is likely to stimulate evaluative and interpretive questioning. Although I agree with Murris that the relationship between text, teacher and child is crucial (2016, p. 243), I would expand the number of items in her list to include multiple texts, teacher, child and multiple worlds. 
A crucial question is: 'Should adults bring to children for consideration issues they regard as important?' I believe they should do so but refrain from manipulating the outcomes of enquiry or striving for a consensus they regard as desirable. This notion of importance is central and unavoidable when philosophising with children. The philosopher, Dorothy Emmet, explained the importance of 'importance' as follows:

Without some judgement of 'importance' we are presented with mere multiplicity of detail, or at best a dead level of facts. A judgement of what is important brings form into a multiplicity, whether in presenting an intellectual theme, or in the practical conduct of life. There is, of course, always the danger that it may impose preconditions; but a preconception can at least sustain interest and later be corrected, whereas a mere manifold of undigested matter of fact can tell us nothing (1966, p. 196)

In my view, reciprocal exchanges between adults and children about what is important are possible and should be encouraged. I think this process is underrepresented in the literature of philosophising with children and perhaps also in practice. Much has been written about the selection of starting points for enquiry and the creation and selection of questions. However, relatively little attention has been paid to a very simple idea: sitting down with children and asking: What is important to you at the moment? What excites your imaginations? What makes you angry or hopeful? The teacher would then help put together a programme of enquiries and events to explore those concerns and seek out philosophical dimensions in the topics to be discussed. I think, also, that children would expect their teachers to put topics on the philosophical agenda and give reasons for doing so. In an age of climate change, pandemics, and obvious injustices around the world, I think children will welcome such an on-going dialogue. That is not to say that all dialogue with children should be initiated using this strategy, only that it would play a significant role within the overall practice. Enlightenment without manipulation could be taken as a regulative ideal - a goal that may never be achieved in every respect but that regulates practice. That is because enlightenment, taken to be a broadening of experience and an enhancement of capacities, is a worthy aim. 
Murris (2016, p. 163) refers to Malaguzzi (1998, p. 73) and insists (against her own advice to beware of binaries) that educators should understand that children are producers of knowledge and not consumers. In my view, this is a binary that, in the context of education, does need blending. Children are, at the same time, both consumers and producers of knowledge. Respectful dialogue, with all its difficulties, is the medium of choice for achieving this complementarity.

references

Bakhtin, M, Translated by Vern W. M. (1986) The Problem of the Text. In: Speech Genres and Other Late Essays, Austin: University of Texas Press, 1987

Blum, L. 'I'm not a racist but ...' The Moral Quandry of Race, Ithaka and London: Cornell University Press, 2002

Chetty, D. The Elephant in the Room: Picturebooks, Philosophy for Children and Racism, childhood $\mathcal{E}$ philosophy, rio de janeiro, volume 10, number 19, pp. 11-31, 2014

Emmet, D. The Nature of Metaphysical Thinking, London: Macmillan, 1966

Haynes, J; Murris, K. Picturebooks, Pedagogy and Philosophy, New York, London: Routledge, 2012 Hirschfield, L. The Conceptual Politics of Race: Lessons from Our Children, Ethos, 25(1), pp. 63-92, 1997

Kendi, I.X. Stamped from the beginning: The definitive history of racist ideas in America, London: Bodley Head, 2016

Kolakowski, L. (1990) Education to Hatred, Education to Dignity in Modernity on Endless Trial, Chicago: University of Chicago Press, 1990

Lester, J, Let's Talk About Race, HarperCollins, 2008

Lipman, M. Harry Stottlemeier's Discovery, Montclair: IAPC, 1982

Lyndon, D. Africa and the Slave Trade UK edition, London: Franklin Watts, 2013

Malaguzzi, G. History, Ideas and Basic Philosophy: An interview with Lella Gandini. In: Edwards, C. Gandini, L. Forman, G (Eds) The Hundred Languages of Children: The Reggio Emilia approach - Advanced Reflections (2nd. Edn), WEsport CT: Ablex

McKee, D. Tusk Tusk, London: Andersen Press, 1978

Murris, K. Posthumanism, Philosophy for Children, and Anthony Browne's 'Little Beauty', Bookbird: A Journal of International Children's Literature, Volume 53, Number 2, pp. 59-65, $2015 \mathrm{a}$

Murris, K. The Philosophy for Children Curriculum: Resisting 'Teacher Proof' Texts and the Formation of the Ideal Philosopher Child, Studies in Philosophy and Education - 35: 63, 2015b Available at <https://doi.org/10.1007/s11217-015-9466-3> Accessed 24 July, 20018

Murris, K The Posthuman Child: Educational transformation through philosophy with picture books, New York, London: Routledge, 2016

Sprod, T. Books into Ideas, Melbourne: Hawker Brownlow, 1993

Tan, S. The Rabbits, London: Hodder Children's Books, 2010

Warden, C. Talking and Thinking Floorbooks: An Approach to Consultation, Observation, Planning and Assessment in Children's Learning, 3rd. revised addition, Scotland: Mindstretchers, 1995 
philosophical dialogue with children about complex social issues: a debate about texts and practices

West, A. Reading Against the Text: Developing Critical Literacy, Changing English, 1:1, 82-101, 1994

Williams, S Artful Dialogues, Teaching Thinking, 19, Birmingham: Imaginative Minds Ltd, 2002

Woodson, J, Illustrations by Lewis, E.B. The Other Side, G.P. New York: Putnam's Sons, an imprint of Penguin USA, 2001

Woodson, J. The other side, available at <https://www.jacquelinewoodson.com/the-otherside> Accessed 23 July, 2018.

Zeldis, Y. D. Who Was Rosa Parks? New York: Grosset \& Dunlap, 2016

Zipes, Jack. Breaking the Magic Spell: Radical Theories of Folk and Fairy Tales, London: Heinemann, 1979

Zipes, J. Fairy Tales and the Art of Subversion (2nd edn.) New York: Routledge, 2012

received in: 16.02 .2020

approved in: 10.06 .2020 